\title{
Regional strategy map as a development tool of resort and recreational area affected by the chornobyl accident (on the example of Zhytomyr region)
}

\author{
Kaminetskiy Vitaliy ${ }^{1}$ \\ ${ }^{1}$ The Senior Lecturer of the Department of Public Administration, Interregional Academy of Personnel Management, Kyiv
}

\begin{abstract}
The resort and recreational sphere of Zhytomyr region as the territory affected by the Chornobyl accident has been studied. The necessity to revive the radiation-affected areas of Zhytomyr region by developing a regional strategy map (RSM) of Zhytomyr region, which determines the directions and measures of the resort-recreational activity of the region, creating a synergistic effect, stimulate its spacetime development.
\end{abstract}

Keywords: public authorities, territory affected by the Chornobyl accident, resort and recreational sphere, resort and recreational services.

\section{Introduction}

At the regional level, which is a holistic socio-ecological-economic formation, the development of the resort and recreation sphere involves consideration of the peculiarities of the natural resource potential, regional job market, specialization, addressing the interaction of services and local needs, etc. Particular attention is paid to the issue of revival and development of the resort and recreational sphere of Zhytomyr region as the territory affected by the accident at the Chornobyl nuclear power plant. A strategic approach to managing the development of resort and recreation services should take into account the advantages of the spatial location of the economic entities that produce the resort and recreation and tourist products, their socio-economic and transport-servicing links, etc. [Ошибка! Источник ссылки не найден.]. At the same time, it is important to highlight and analyze extensive, intense and constraining (negative) factors when substantiating the development of any resort and recreation region [Ошибка! Источник ссылки не найден.]. Parallel to this, justifying the development of any resort and recreation region it is important to identify and analyze extensive, intense and constraining (negative) factors.

The objective of the study is substantiation of theoretical and methodological foundations for the development of a regional strategy map (RSM) to determine the priority of management of the regional resort and recreational sphere of Zhytomyr region.

\section{The study results}

Analyzing the resort and recreation sphere of Zhytomyr region, particular attention is paid to radioecological, socioeconomic and socio-psychological situation of its territory. At this point, the higher goal is revive the radiation-affected areas of Zhytomyr region. This can be achieved not only by ensuring safe living conditions, economic activity, but also by the development of the resort-recreation and tourist spheres. Accordingly, the development of the RSM of Zhytomyr region determines the directions and measures of the resort-recreation activity of the region, and stimulates its spacetime development, creating a synergistic effect,

Potentially attractive for tourists balneological, climate, water, forest, biotic natural resources influence on formation and development of resort and recreation needs of Zhytomyr region. At the same time, Zhytomyr region is full of historical and cultural recreational resources. Each area is full of historical and cultural recreational resources. Ancient churches, fortresses and houses are witnesses of historical events of the princely era, Polish-Lithuanian and Moscow rule, the Cossack state. The life path of famous Ukrainian and world culture figures, historical leaders, public and political figures is connected with the lands of the region. Paradoxically, tourism can develop in this region, although no one expected it. According to the Ministry of Environmental Protection of Ukraine, which takes care of the exclusion zone around the Chornobyl nuclear power plant, about 10 thousand people visited the site in 2015,70 thousand - in 
2014, and the number of visitors was already 75 thousand - in 2016, 80\% of them are foreigners. Among the foreign countries the record holders were Great Britain (15 738 tourists), Poland (9 378), Germany (7 826), the USA (5 580) and the Czech Republic (4 063). Many Ukrainians were among the guests of the zone - 22468 peоple [Ошибка! Источник ссылки не найден.]. The UN proposed to create a tourist zone in Chornobyl. The proposal stated that, despite exceeding the permissible level of radiation, the UN considers it possible to invite tourists to Chornobyl, and the money raised from "extreme tourism" would be used for the aid and treatment of thousands of poor Ukrainians affected by the Chornobyl tragedy [Ошибка! Источник ссылки не найден.]. These and other factors determine the directions of strategic development of resort-recreation entities of the "post-Chornobyl territories", based on the prospects of development of the actual sphere of resort-recreation services and available infrastructure, which are affordable due to such an instrument as the RSM and accumulates the following strategies [Ошибка! Источник ссылки не найден., с. 70] :

\# a strategy of fundamental change - elucidation the causes of the crisis and finding ways to support and rehabilitate the monofunctional recreation-oriented economy affected by the radiation of the territories, attracting investments, re-profiling the resort, etc .;

* a strategy of maintaining growth - support of the necessary growth rates of the resort industry, recreation and tourism under adverse external conditions, competitive pressure, etc. etc. by attracting tourists through the introduction of new resort and recreation services, improving the quality of service, infrastructure development;

* a strategy of growth retention - aimed at maintaining the achieved level when the resort and recreation sphere will not be able to develop a new product and refocus it on a new market;

* a strategy of selective growth - targeted at a specific segment of the market, incl. through the introduction of new services, aimed at enhancing their competitiveness.

In accordance to the allocated strategic guidelines, the goal of development of an integrated RSM of the resortrecreational sphere of Zhytomyr region, is conducting scientific research, management, legal and economic measures to create a proper organizational-legal and organizational-economic base for the further development and modernization of the resort and recreational economy of the territory.

To achieve this goal, the main objectives and tasks in the area of overcoming the consequences of the Chornobyl disaster have been defined - further reducing the risk of adverse effects on the health of citizens, facilitating the transition from the rehabilitation of territories to their sustainable socio-economic development while unconditionally ensuring the requirements of radiation safety, creating more attractive conditions for the development of the resort and recreational sphere of Zhytomyr region.

Therefore, it is necessary to have clear signposts, which are the concept and strategy of the development of the resort-recreational sphere, to improve its legislative and regulatory framework. The controversy and coherence of the last one, as well as its compliance with modern requirements, its compliance with modern requirements is an important prerequisite for further success of the development of the regions. As the legislative base determines the general legal, organizational and socio-economic principles of the implementation of state policy, and the legal framework - specifies these principles, regulates and controls the action of the organizational and economic mechanism of functioning of the resort-recreational economy of the regions [Ошибка! Источник ссылки не найден.].

In return, the organizational-economic support for the further development and modernization of the resortrecreational sphere of the territory implies the formation of a structure consisting of interacting resort-recreational and tourist territories of the region with resort-recreational and tourist facilities located there, integrated infrastructure (including public transport) and a public administration system. At the same time, the activity of public authorities should be directed to detailed elaboration of the planning structure of each resort-recreational and tourist area; to creation business plans and project documentation for specific resort-recreational and tourist sites; to the formation of marketing programs that ensure the promotion of all types of resort- recreational and tourist activities on the market, both local authorities and business entities. It should be noted that by increasing in the scope of activities and the number of levels of the sustainable development management system, some negative consequences of the complication of its architecture can be eliminated through the use of the criterion approach for the evaluation/forecasting of macroeconomic indicators. The objectivity of diagnostics provides the definition of the key dominants of sustainable development, which can be synthesized in the RSM of Zhytomyr region and combined in the following major components:

\# determining measures for the development and implementation of special projects and programs aimed at creating conditions for the sustainable development of the affected area;

* continuation of implementation of measures that contribute to reducing the radiation dose of the population through the improvement of built-up areas located in the territory of radioactive contamination, construction and reconstruction of roads, water supply system, water treatment facilities and drainage in 
these localities; realization of investment projects (construction of objects of transport, education, culture and sports, household, commercial, social, communal, agricultural, safe life activity), aimed at socioeconomic development of the affected areas of Zhytomyr region;

\# production of competitive regional resort-recreational product/services, as a result of the introduction of system marketing activities, which leads to beneficial positioning of different types of resort-recreational products, adapted to the changing demands of tourists;

* ensuring the rational and integrated (social, economic, environmental and innovation support) use of available tourist and resort-recreational resources through improvement of the system of resortrecreational natural resource utilization and protection of the natural landscape ecosystem $i$ with the purpose of development of resort-recreational territories and their branding;

* complex formation of high-quality infrastructure of resorts and tourist-recreational territories through effective implementation of a comprehensive program of modernization of the material-technical base;

* ensuring parity price and quality of resort-recreational and tourist products by optimizing the organizational and economic structure of the business environment for the activities of small and mediumsized enterprises in this field;

* development of regional quality management standards for the production of resort-recreational product and providing complex resort-recreational services in accordance with international requirements;

* adaptation of national and regional statistical account system to foreign analogues;

\# introduction of the system of quality training, retraining and skills development of specialists of the resortrecreational industry and service industry, as well as other occupations in the sphere of tourism and resorts;

* creation of information content of resort-recreational and tourist services through the functioning of information centers of resort-recreational and tourist services and promotion of relevant products/ services during the organization and participation in fairs.

With the current level of development of methodology for identifying the parameters of sustainable development of Ukraine and practical diagnostic tools, it is possible to provide new content to the target functionals, tasks to ensure the practical orientation of the RSM, which provides:

\# inclusion of the resort-recreational sphere in the "Strategy of development of Zhytomyr region till 2027";

* development of the "Brand Formation Program "Resort-recreation services of Zhytomyr region"”;

* development of "Marketing resort-recreation strategy of Zhytomyr region till 2030";

* categorization of accommodation facilities by generally recognized international standards.

Performing tasks and achieving the main goal, identified in the RSM can be secured through the introduction of a European model of public-private partnership. This management model makes it possible to ensure rational use of tourist and resort and recreational resources of Zhytomyr region; to boost job growth; to form a positive tourist and resortrecreational image of the region and the country in general; to increase revenues to state and local budgets; to achieve relatively high social and environmental effectiveness from resort-recreational activities.

Overall, the expected results and effectiveness of the use of RSM will enable:

\# to restore and strengthen the existing material and technical base of the resort-recreational and tourist sphere as a type of economic activity and an important social institute of Zhytomyr region;

* to create a quality resort-recreational product, that can able to meet the needs of its population as much as possible;

* to develop the tourism potential of Zhytomyr region by: promoting and developing tourism, which should become one of the directions of the revival of the Chornobyl territories, in particular "post-accident tourism", as well as weekend tourism and ethno-tourism; creation and promotion of Zhytomyr tourism brand; formation of ecological perception of the population; improving the status of resort-recreational areas, clean-up of the natural recreational areas and territories around localities; creation of a modern solid waste management system and others.

\section{Conclusions}

Recognition of the priority of regional resort and recreation management through strategic innovation management becomes apparent. As noted above, the development of a regional strategy map, which helps to increase the efficiency of the formation and implementation of socio-economic processes at the regional level is of paramount importance in strategic regional governance. Thus, the implementation of a regional strategy map, on the one hand, can outline the strengths and weaknesses of regional development, and on the other hand, determines the directions for corrective external and internal influences. The involvement of a particular RSM unit is informative and allows to identify the problem areas of the regional system for further change its strategic goals. 


\section{References}

[1] Ustojchivoe razvitie turizma. (1993). [Sustainable tourism]. Madrid, VTO. [in Russian].

[2] Chornobyl' turystychnyj. Yak planuiut' rozvyvaty zonu vidchuzhennia? [Chernobyl is tourist. How do you plan to develop the exclusion zone?]. Retrieved from https://petropavlivka.city/read/card/52031/chornobil-turistichnij-yak-planuyut-rozvivatizonu-vidchuzhennya [in Ukrainian].

[3] Chornobyl': turystychni aspekty. (2001). [Chernobyl: tourist aspects]. Retrieved from http://www.myslenedrevo.com.ua/uk/Sci/Local/Chornobyl Tourism.html\#3 [in Ukrainian].

[4] Rjabcev, A. A. (2010). Nauchno-metodicheskie aspekty strategicheskogo planirovanija razvitija sfery turistsko-rekreacionnyh uslug [Scientific and methodological aspects of strategic planning for the development of tourism and recreational services]. TERRA ECONOMICUS, 2. Retrieved from file://C:/Users/Admin/Downloads/nauchno-metodicheskie-aspektstrategicheskogo-planirovaniya-razvitiya-sfer-turistsko-rekreatsionn-h-uslug\%20(1).pdf [in Russian].

[5] Kucenko, E. I. (2014). Innovacionnaja politika kak instrument perehoda k ustojchivomu razvitiju regiona [Innovation policy as a tool for the transition to sustainable development of the region]. Menedzhment v Rossii i za rubezhom, 3, pp. 79-84. [in Russian]. 